\title{
From the Industrialization Model by Import Substitution (ISI) to the Open Model Adopted in Colombia Since 1991
}

\author{
Hernando Hernández Lasso \\ National University of Colombia
}

\begin{abstract}
This paper seeks to identify why Colombian industry was lagging at the time of its economic opening, as well as to identify the causes of failure of the Import Substitution Industrialization (ISI) model. To this end, two economic models seeking industrialization in Colombia are presented and contrasted. The impact of the post-1991 "aperturist" economic opening model is examined through several indicators, to elucidate the causes of the failure of the ISI model. This work is mainly inspired by the publications of Misas Arango, Bértola and Ocampo.
\end{abstract}

Keywords: Economic Opening, Industrialization by Substitution of Imports, Industrialization

\section{INTRODUCTION}

The models discussed in this work have affected the development of the Colombian economy. The Industrialization Model by Import Substitution (ISI), which was in force from the end of the nineteenth century through 1991 (Misas Arango, 2016), facilitated the economy's biggest boom for three decades under the mantle of the Cepalian structure. Later, the opening model created large changes in trade balance and productivity and also increased the number of billionaires in the country. Promoted by the governments of Caesar Gaviria, Ernesto Samper, Andrés Pastrana, Alvaro Uribe and Juan Manuel Santos, the latter model is currently in force, and has led to free-trade treaties, including one with the United States signed on May 15, 2012.

The main objective of this work is to address the question of why Colombian industry was lagging behind at the time of economic opening, and what caused the fall of the ISI model. To that end, and in order to familiarize the reader with the Colombian economic models of the last century, an overview of the ISI and Aperturist models are presented. The implementation and impact of these models on the economy of Colombia are then analyzed. Finally, conclusions and possible areas for future study in this area are shared.

\section{CONCEPTUALIZATION}

The evolution of the ISI model is outlined, including the main variables implemented in the five phases of its application from the end of the 19th century through 1991. These phases are (i) state intervention; (ii) policy approaches to maintain international reserves; (iii). creation of the Economic Commission for Latin America and the Caribbean (ECLAC), which implemented the protectionist and interventionist role of the state, (iv) the consequences of an inferior domestic industry relative to other 
countries, which suggested the need for change; and (v) transition to an open economy, the aperturist model. However, the main characteristics of the aperturist model are an international regime, growth and productivity, monetary regime, deregulation and capital-to-work relations. Figure 1 describes the relationship between each of these characteristics, as laid out in the work of Masses (2016).

\section{FIGURE 1 \\ EVOLUTION AND VARIABLES OF THE ISI MODEL AND STRUCTURE OF THE APERTURIST MODEL}

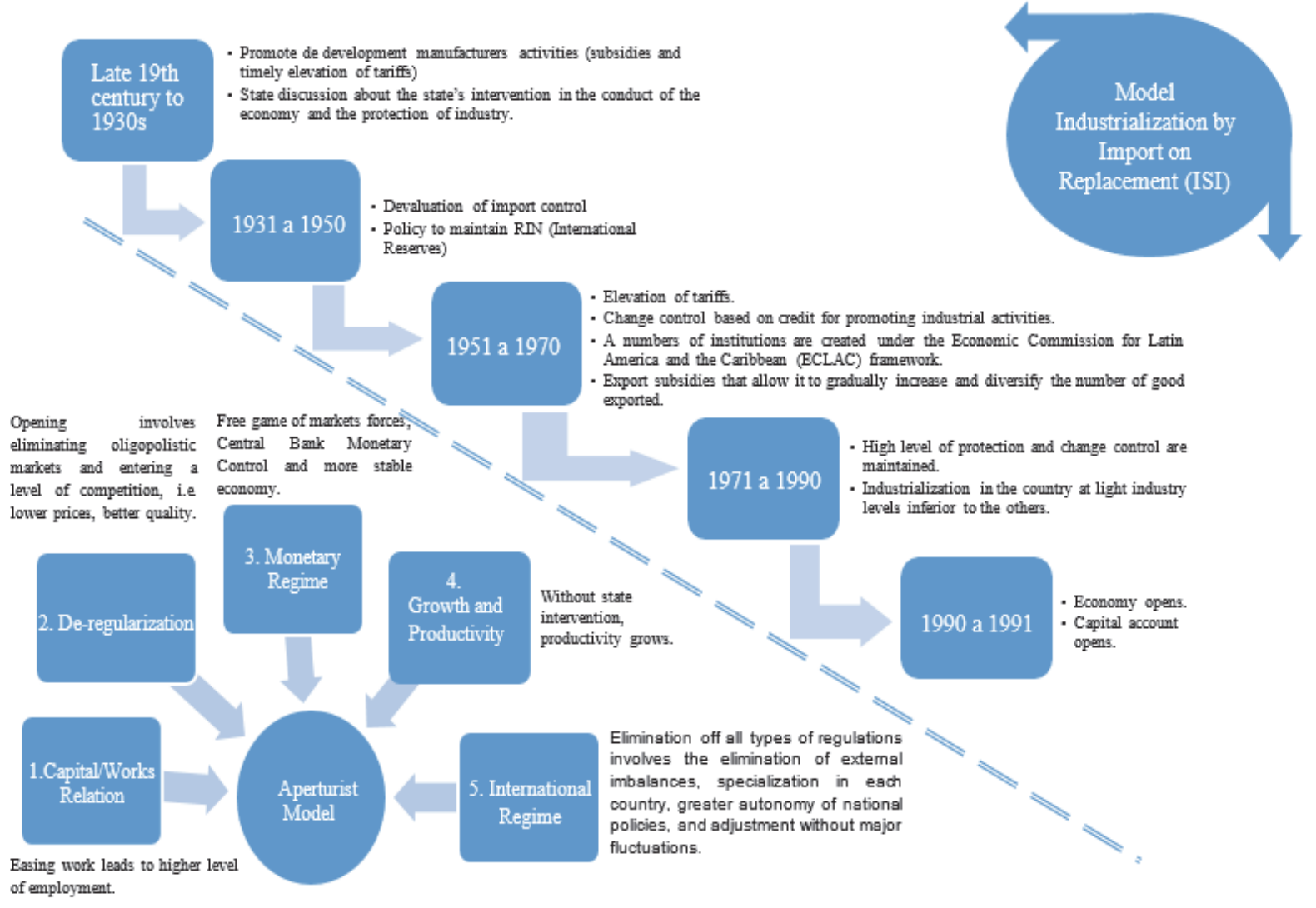

Author's work, based Misas Arango, 2016

Figure 1 conceptualizes the structure of the ISI model created by South American economists, including Raúl Prebisch, Celso Furtado and Anibal Pinto selected from the Economic Commission for Latin America and the Caribbean (ECLAC) and the model of economic openness pioneered by Ronald Reagan and Margaret Thatcher. The work of Torres (2014) to elucidate the differences between these two models is described in Table 1. 
TABLE 1

COMPARISON OF THE APPROACHES OF THE ISI AND APERTURIST MODELS

\begin{tabular}{|c|c|}
\hline ISI Model & Aperturist Model \\
\hline High effective protection rates & $\begin{array}{l}\text { Policies opening up goods and services to } \\
\text { international markets }\end{array}$ \\
\hline Quantitative import restrictions & Reduced import taxes \\
\hline $\begin{array}{l}\text { Overvaluation of the exchange rate } \\
\text { (revaluation weight) }\end{array}$ & Liberalization of the capital movement \\
\hline $\begin{array}{l}\text { Preferential treatment in imports of raw } \\
\text { materials and machinery for industry }\end{array}$ & $\begin{array}{l}\text { New guidelines involving the reduction } \\
\text { of the role of the State as an enforcer and } \\
\text { regulator of the economy and society }\end{array}$ \\
\hline Preferential access to credit & $\begin{array}{l}\text { Credit for productivity and competitiveness } \\
\text { in the market }\end{array}$ \\
\hline Low tax rates & $\begin{array}{l}\text { Revenue growth by encouraging increased } \\
\text { investment in development }\end{array}$ \\
\hline Benefits state and protectionist economy & Privatization of public enterprise \\
\hline $\begin{array}{l}\text { High performance burden, vicious circles } \\
\text { in government procurement and financial } \\
\text { market without opening borders. }\end{array}$ & $\begin{array}{l}\text { Deregulation of labour, health and financial } \\
\text { markets. }\end{array}$ \\
\hline
\end{tabular}

Once the function of each of the models has been described, the radical opposition between the two is evident. Notably, the protectionist level of the state at the level of imports are maintained in both (as presented below in depth for the application and impact of the aperturist model). Unemployment and productivity indicators are provided (Tables 2 and 3 ) to help the reader understand the failure of the ISI model.

TABLE 2

UNEMPLOYMENT RATE BY YEAR

\begin{tabular}{|l|l|l|l|}
\multicolumn{1}{|c|}{ Year } & $\begin{array}{c}\text { Unemployment } \\
\text { rate (\%) }\end{array}$ & Year & $\begin{array}{c}\text { Unemployment } \\
\text { rate (\%) }\end{array}$ \\
\hline $\mathbf{1 9 6 4}$ & 6.8 & $\mathbf{1 9 8 8}$ & 12.7 \\
\hline $\mathbf{1 9 6 7}$ & 12.3 & $\mathbf{1 9 8 9}$ & 10.9 \\
\hline $\mathbf{1 9 7 4}$ & 10.4 & $\mathbf{1 9 9 0}$ & 9.7 \\
\hline $\mathbf{1 9 8 0}$ & 9.7 & $\mathbf{1 9 9 1}$ & 10.5 \\
\hline $\mathbf{1 9 8 5}$ & 13.9 & $\mathbf{1 9 9 2}$ & 10.7 \\
\hline
\end{tabular}

Source: Maya, 1992

TABLE 3

PRODUCTIVITY RATE INDICATORS

\begin{tabular}{|c|c|}
\hline Period & Growth rate: Productivity/Year (\%) \\
\hline $\mathbf{1 9 3 0 - 5 0}$ & 2.8 \\
\hline $\mathbf{1 9 5 0 - 7 0}$ & 1.4 \\
\hline $\mathbf{1 9 7 0 - 8 0}$ & 0.8 \\
\hline $\mathbf{1 9 8 0 - 9 0}$ & -0.6 \\
\hline
\end{tabular}

Source: Maya, 1992 
Indicators show that during the years the Colombian economy was guided by the ISI model, the unemployment rate was quite high. This, no doubt, was one of the reasons why the model was on the verge of a big decline. The rate of productivity growth also shows the immense disadvantages of the model, which, even after the economic opening, have not changed.

In 2018 , the unemployment rate was $9.5 \%$ and the growth rate $2.5 \%$. This combination shows that the economy exceeded the negative growth of $-0.6 \%$ present in the period $1980-90$, but has not recovered in terms of unemployment. Colombian industry appears to have "grown inward" in that period, a result contrary to the approach of the Cepalian model: it was easier to import goods from China than to sponsor domestic production. Then, companies were starting to privatize and to make direct purchases of financial monopolies, telecommunications and energy to multinational companies. Vega (1999) explains the causes of the model's decline:

The ISI model fell into crisis because the social coalition had come to an end at the political level, because class issues divided work and capital creating difficulty in maintaining a common policy; it should be clarified that the possibility of moving from consumer goods to capital goods and to the investment of cutting-edge technologies was a feasible path (p.186).

Jaramillo (1992) stated that at that time, not only internal development, but globalization, was about to establish itself and "force" economic neoliberalism, as the ISI model was clearly not working. It is true the currency crisis of the period was not only due to local mishandling of economic policy, but that several exogenous factors, such as high foreign interest rates, and the devaluation of Venezuelan currency, and relatively weak coffee prices on the international market influenced the deficit.

In the face of one party's misfortune, others can take advantage of the situation. In Colombia, this was the case with the International Monetary Fund (IMF). Escobar (2014) discusses how the difficult situation the country was going through forced radical decisions to be made that allowed the country to overcome the crisis:

In this situation, the Colombian government is forced to finance this deficit in order to avoid a possible economic crisis at a later date and first turns to the IMF. In return for this loan, the IMF issues Colombia with a series of economic policy recommendations that could help improve the country's situation, including trade opening (p.12).

Ortiz's case study (2009) show that the exaggerated protectionism of the ISI model led to industrial inefficiency. He presents the consequences of the model for the Colombian economy, stating that:

With preferential state funding, high effective protection and high market power, domestic industry was given the luxury of investing in suboptimal technologies. Nascent industries demanded protection to develop, but they never matured, as the State never required them to export or increase productivity, and they became dependent on state support (p.14).

Sarmiento (1996) mentions that economic openness wiped out much of Columbia's existing industry due to the low systemic competitiveness of the national economy and the lack of industrial development and infrastructure. Sarmiento further indicates that the liberation of Columbia's market for goods and of its exchange rates happened almost simultaneously, creating a negative imbalance in the balance of payments and a reassessment that affected domestic industry. 


\section{Application and Impact of These Models in Colombia}

- During the government of César Gaviria (1990-1994), industrial exports from Columbia declined from $61.7 \%$ to $43 \%$. After 20 years of the aperturist model, mining exports (carbon, petroleum derivatives, iron, nickel and gold have grown very little, from $15 \%$ in 1994 to $16.7 \%$ in 2014 . Figure 2 shows the behavior of this sector; although there are surpluses in some minerals, exports have not grown markedly (Torres, 2014).

\section{FIGURE 2 \\ TRADE BALANCE OF MINERALS COLOMBIA 2000-2012 (US\$ MILLIONS)}

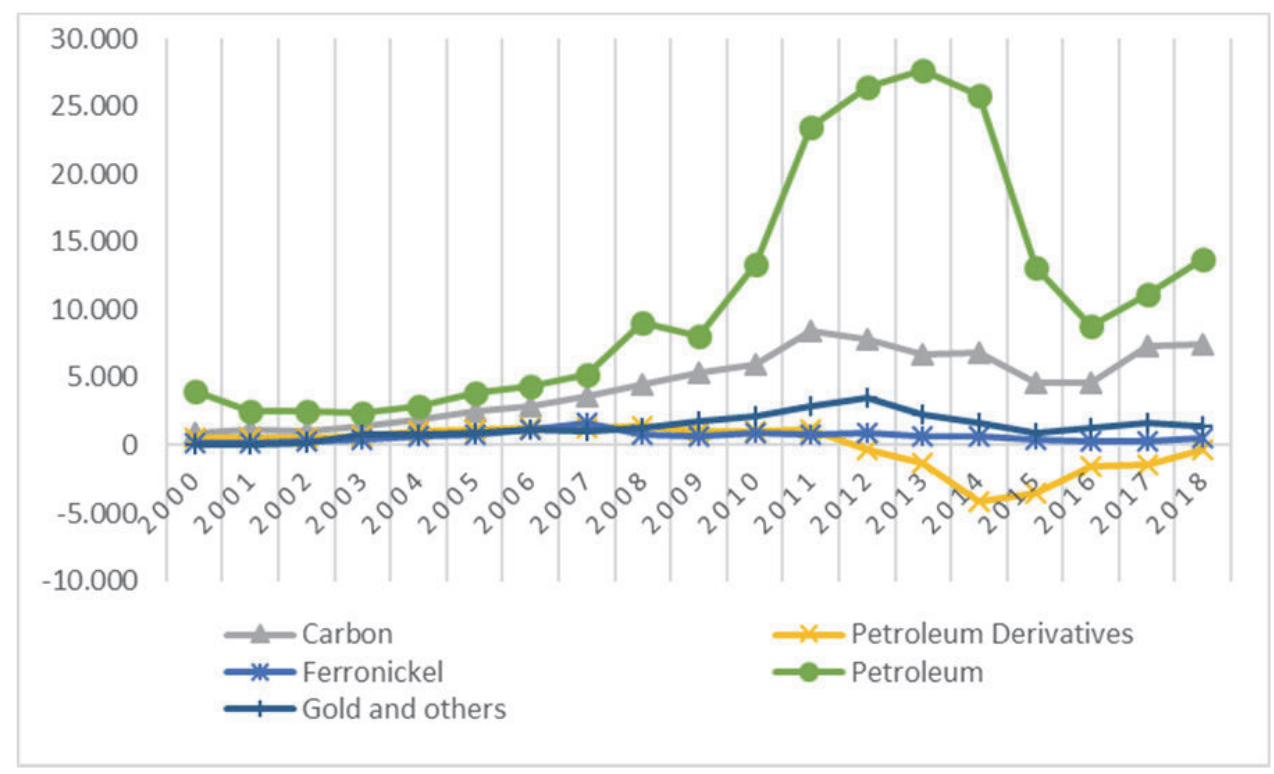

Author's work, based Torres, 2014

- This model changes the logic and enlarges the advantage in the sense of purchasing power that the capitalist elite possess, since

Liberalization and structural adjustment policies have played a strategic role in the opening up of Latin America to exploitation and the United States and in the provision of a key source of income, to compensate for the loss of U.S. competitiveness in other regions. At the same time, liberalization creates a new network of Latin American billionaires who increasingly dominate national policies and economies, and are important partners of American banks and transnationals (Vega, p.195).

- Since 2002, the presidency of Alvaro Uribe Velez (2002-2010) has emphasized policies granting special benefits to specific groups.

During the Uribe administration, trade policy measures were taken to raise protection for some of the sectors benefited above, a goal that was achieved without raising the average tariff. Indeed, the average tariff rose from $11.6 \%$ in 2002 to $12.1 \%$ in 2005 (García, López, Uribe, Esguerra, p.48). 
- Further adjustments to Colombian trade policy were made by the government of President Juan Manuel Santos (2010-2018).

The first was major tariff reform in October 2010, which reduced the average rate from $11.6 \%$ to $8.5 \%$. This measure lowered tariffs on almost all products except vehicles and most agricultural products and agribusiness, items that had traditionally been subject to higher tariffs. The measure was taken in order to increase import demand and reduce exchange rate pressure; despite this reduction, Colombia's average tariff has generally exceeded that of other more open economies, such as Chile and Peru (García et al., p.50).

- In addition, according to World Bank data, since Colombia's economic opening, its GDP has increased from $\$ 50$ billion to $\$ 350$ billion. This shows that total production has increased substantially with neoliberalism, even though in 2014 it fell along with the downturn of oil prices. Figure 3 shows this behavior.

\section{FIGURE 3 CHANGES IN GDP IN COLOMBIA}

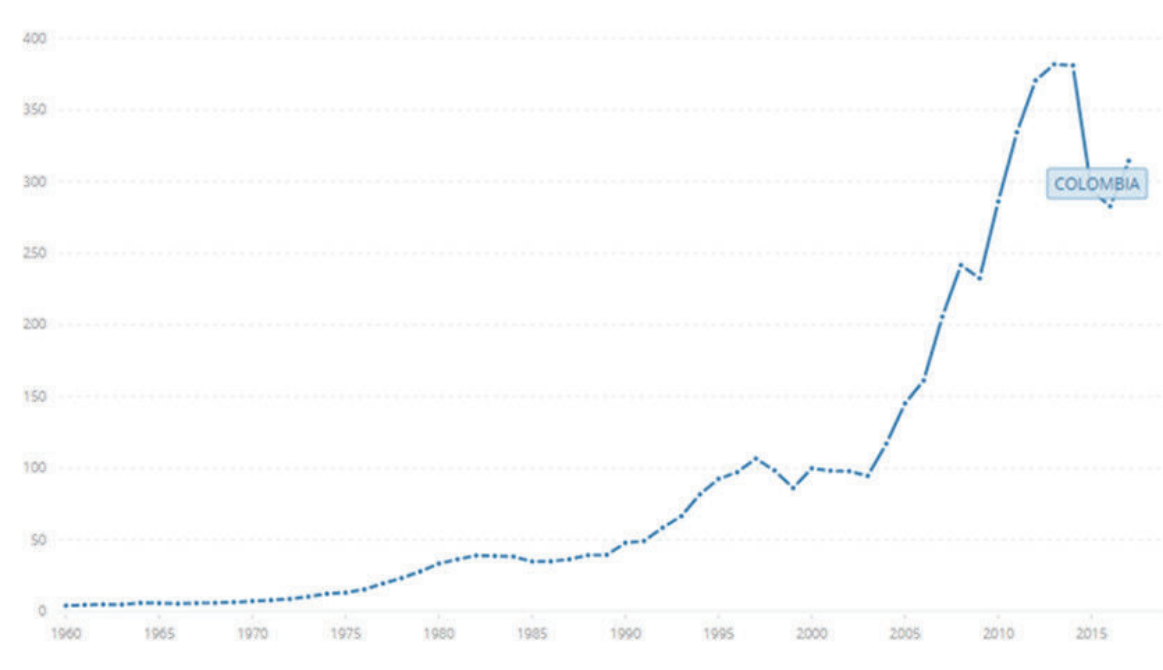

Source: World Bank

\section{CONCLUSIONS}

This work presents the historical economic thinking behind the ISI and aperturist models. It is emphasized that the models adopted by Colombia in both the protectionist and neoliberal eras have had different effects: the former supported domestic industry through subsidies and increased tariffs, while the second prioritizes the importation of capital goods and state-of-the-art technology. The national government should focus on the production and export of consumer goods.

With the arrival of the model of the aperturist model in Colombia in 1991, the number of billionaires in the country increased (Vega, 1999), as well as the number of middle class families. In 1984, most of the population of Colombia was low-income, with about $10 \%$ middle class, but as the aperturist model was adopted, the country escaped poverty (low- to middle-income), and substantially decreased the average income (Departamento Administrativo Nacional de Estadística, DANE). Thus, in 2016, 26\% of the country were classified as middle-income families. At the time of writing (2019), the Columbia's 
median-high income has been stagnants for the last five years, following substantial progress in the previous three decades.

In this work, the author asserts that the model of industrialization by substitution of imports reached a crisis ending its implementation due to the generation of alarming rates of unemployment. Domestic industry did not feel it was imperative to produce goods of high quality and high price because their operation depended not on profits obtained from sales, but on state subsidies. In addition to being gigantic, the role of these subsidies in business productivity was not monitored. Consequently, companies were not motivated to increase production capacity and provide employment. This caused Colombian industry to lag compared to other countries, as weak confidence in the sector did not draw international investment, in turn keeping GDP low. However, it is not known that in the per-tourist model the unemployment rate has remained equally close to the two figures.

This trial could later be a source of resources for analyzing the nation's convergence. The Spanish author Sala-i-Martin, a researcher on macroeconomic convergence issues, claims that by overheating their economy, increasing their productive capacity and technical development, third-world countries are growing, while first-world countries are coming to a time of stagnation with reduced production and slowed growth. Soon, underdeveloped countries may find themselves joining the ranks of developed countries. The following example better explains this convergence: Consider a country with high average income (e.g. the United States) as being in a high-end vehicle of the latest model, traveling through point $\mathrm{X}$ bound for point $\mathrm{X}+50$ at $10 \mathrm{~km} / \mathrm{h}$, and consider a middle-income country (e.g. Colombia) as traveling in a midrange vehicle, 10 years older, traveling at $60 \mathrm{~km} / \mathrm{h}$ through point $\mathrm{X}-100$, with the same destination, $\mathrm{X}+50$. Without the significant impact of external factors (civil wars, catastrophes, attacks, etc.), at some point these vehicles will meet. At this point, middle-income countries become high-income countries, achieving macroeconomic convergence. Thus, with an open economy, Colombia may become a first-world country in the near future. 


\section{REFERENCES}

Bértola, L., \& Ocampo, J. (2010). Latin America's economic development since Independence, 1 st ed. Mexico.

Departamento Administrativo Nacional de Estadística. (2015). Boletín Técnico, Pobreza Monetaria. Recuperado de: http://www.dane.gov.co

Escobar, S. (2014). Private consumption and economic opening in Colombia 1970-2010: An analysis of structural change (undergraduate thesis). Colombian engineering school Julio Garavito, Bogota, Colombia.

Garcia, J., Lopez, D., Montes, E., \& Esguerra, P. (2014). An overview of Colombian trade policy from 1950 to 2012. Economic Scents Banco de la Republic Magazine, 817.

Jaramillo, A. (1992). Economic openness in Colombia. Eafit University Magazine, 87.

Maya, G. (1992). Economic opening and agriculture in Colombia. Conference at the seminar: Agricultural exports and economic openness.

Misas Arango, G. (2016). From import substitution to economic openness. Difficult industrial consolidation. Bogota, Colombia: National University of Colombia

Ortiz, C. (2009). Colombia's economic slowdown: What is sown is harvested. Journal of Institutional Economy (Research Group on Growth and Economic Development) II, 21.

Sarmiento, E. (1996). Openness and growth: from disillusionment with the new state. Bogota, Colombia: Third World Editors.

Torres, J. (2014). Colombia: achievements in two decades of aperturist development models - analysis according to trade balance results. Political Analysis, 82.

Vega, R. (1999). Neoliberalism: myth and reality. Bogota, Colombia: Editions critical thinking.

Villar, L. (2000). Did the Colombian economy open up or shut down in the 1990s? A note on indicators of economic opening. Journal of the Bank of the Republic, 867. 